\title{
The linen-bearers procession carrying straps in both hands in the private tombs of the old kingdom
}

\begin{abstract}
This article deals with the scene of the procession of linen-bearers carrying straps in both hands in the private tombs of the Old Kingdom. This scene is collected from the tombs. The positions of representations of the scene, numbers of processions in the tomb, and numbers of linen bearers in the procession are studied. Direction of the procession and distribution of this scene in the cemeteries are introduced. Identity of the tombs owners who depicted linen bearers and inscriptions accompanying the linen bearers are identified. Dating of the scene is studied.
\end{abstract}

Keywords: old kingdom, saqqara, tomb decoration, linen, linen bearers, linen straps
Volume 4 Issue $6-2019$

\author{
Saleh Soleiman,' Doaa Atef ${ }^{2}$ \\ 'Department of Egyptoloy, Faculty of Archaeology, Damietta \\ University, Egypt \\ ${ }^{2}$ Department of History, Faculty of Arts, Damietta University, \\ Egypt
}

Correspondence: Saleh Soleiman, Department of Egyptoloy, Damietta University, Egypt, Tel 0020I0I8398834,

Emailsaleh_suleiman82@yahoo.com

Received: October 16, 2019 | Published: December 20, 2019

\section{Introduction}

The Ancient Egyptians decorated their tombs in the Old Kingdom with different scenes and writings. One of these is the linen offering, which may mean the presentation of new or clean clothing, ${ }^{1}$ and which appeared in different contexts, including linen production, ${ }^{2}$ filling the boxes with linen, a separate list for linen, ${ }^{3}$ inside the traditional long offering list, ${ }^{4}$ inside the thousand offering list, ${ }^{5}$ inside packages and boxes depicted on the walls of the tomb super and sub-structures, ${ }^{6} \mathrm{a}$ priest holding and presenting it among the funerary meal rites which are divided into seventeen rites, ${ }^{7}$ linen-bearer with other offering bearers $^{8}$ and processions of linen bearers in closed boxes ${ }^{9}$ or in hands.

\section{Procession of linen-bearers carrying straps in both hands}

This last context, procession of linen bearers in hands, is the subject of this article. It represents more than one person, standing in a horizontal procession, directed to the tomb owner or to the store-room. Each person holds with each hand a strap of linen in front of him. The

${ }^{1}$ Hassan S. Excavations at Gîza, VI [2], Plates, Cairo, 1946, p. 96.

${ }^{2}$ http://www.Oxfordexpeditiontoegypt.com/Database.php $>$ Scene-details Database: Scene: 10.2 .

${ }^{3}$ Smith WS. The Old Kingdom Linen List, ZÄS 71(1935), p. 134-135, 140. ${ }^{4}$ Ibid, 136; Hassan, Gîza, VI [2], Plates, pls. ix, xvii, xxv, xxxiii, xli, xlix, lvii, lxv, lxxiii, Lxxxi, lxxxix, xcviii, cvi, cxv, cxxiii; Barta, W. Die altägyptische Oferliste von der Frühzeit bis zur griechisch-römischen Epoche, MÄS 3, Berlin,1963, p. 14, 17-23, 26-28, 30, 32, 36, 45, 48, 53, 56, 89, 97, 107.

${ }^{5}$ Simpson WK. Giza Mastabas, vol. 3, The Mastabas of Kawab, Khafkhufu I and II, Boston, 1978, fig. 28.

${ }^{6}$ Smith, Linen List, Harpur Y, Scremin P. The Chapel of Kagemni-Scene Details, Oxford, 2006, p. 136, 480-481, pls. 509, 512, fig. 35.

${ }^{7}$ Junker H. Graubünden aufdem friendhof des Alten Reiches bei den Pyramiden von Giza, Band III, Vienne, 1938, p. 100-110; Hassan S. Excavations at Gîza, VI [2], Text, Cairo, 1948, p. 84-99.

${ }^{8}$ Junker H. Grabungen auf dem friendhof des Alten Reiches bei den Pyramiden von Giza, Band II, Vienne,1934, Abb. 11.

${ }^{9}$ Smith, Linen List, p. 140. procession was found in about eight tombs from the Old Kingdom. ${ }^{10}$ We will start our study by organizing them in a table according to their dating, followed by comment (Table 1) (Figure 1-8).

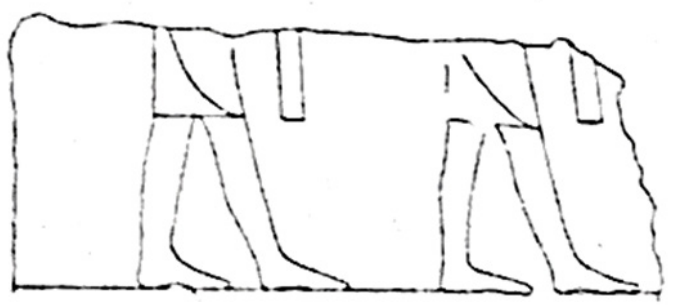

Figure I A Linen-bearers, Nebet's tomb (Munro, Unas-Friedhof, Taf. 29).

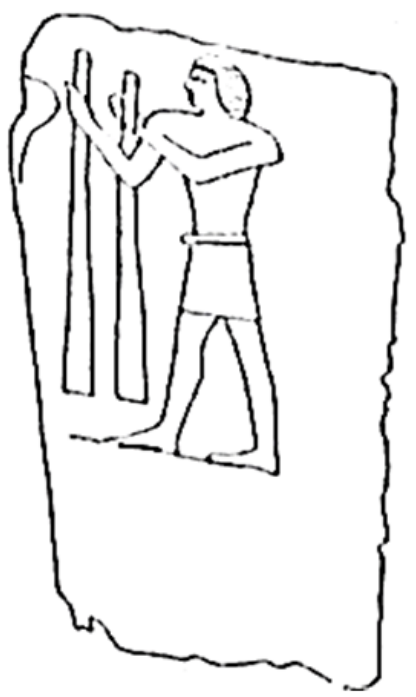

Figure IB Linen-bearers, Nebet's tomb (Munro, Unas-Friedhof, Taf. 43).

${ }^{10}$ Harpur and Paolo, Kagemni, p. 483. 


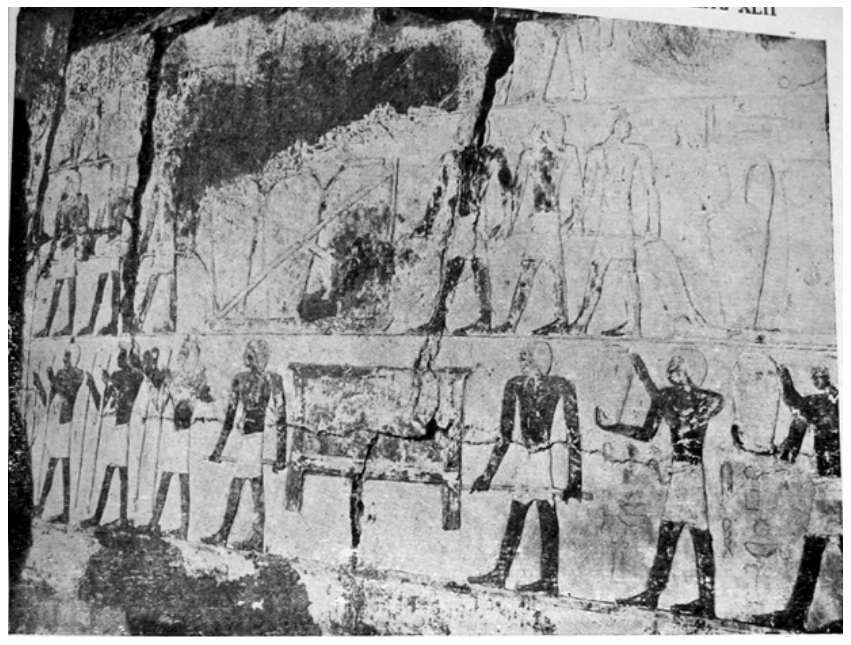

Figure 2A Linen-bearers, Akhethetep's tomb (Hassan, Saqqara, I, pl. xlii).

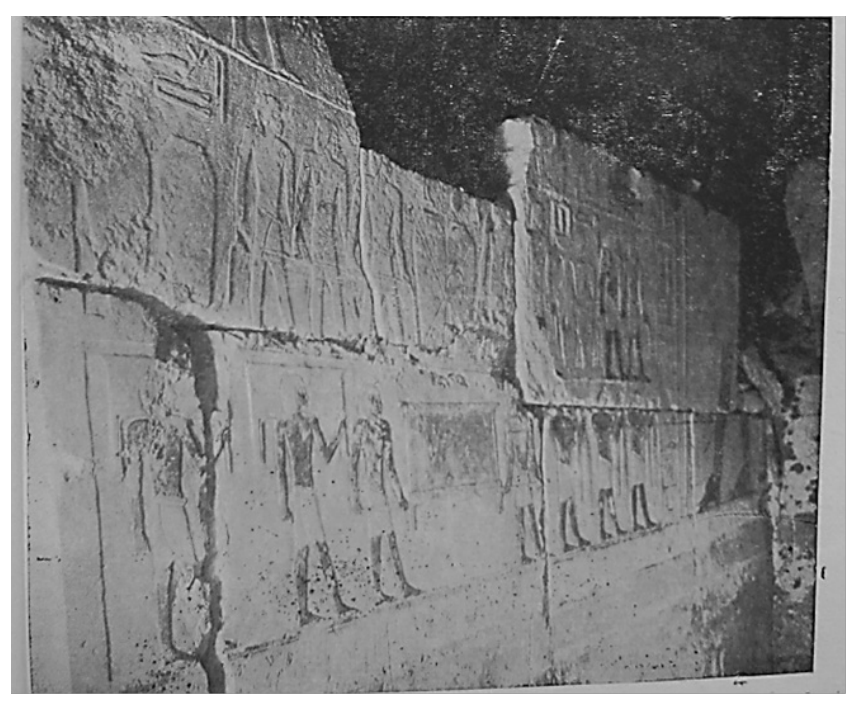

Figure 2B Linen-bearers, Akhethetep's tomb (Hassan, Saqqara, I, pl. xliii).

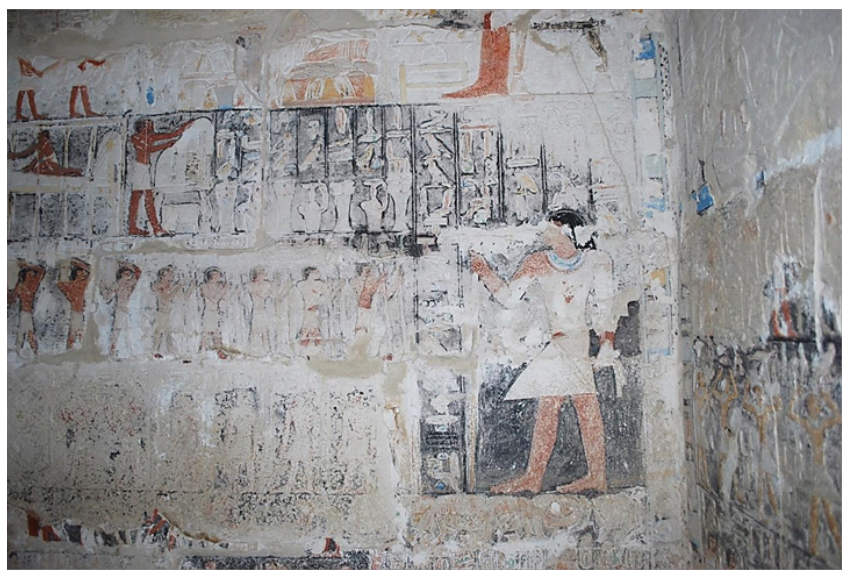

Figure 3A Linen-bearers, Ptahshepses's tomb (Soleiman and El-Batal, Ptahshepses, I, pl. 59).

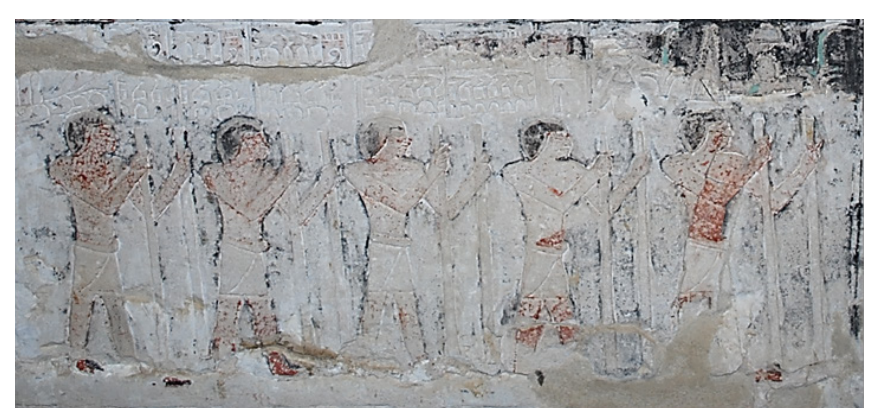

Figure 3B Linen-bearers, Ptahshepses's tomb (Soleiman and El-Batal, Ptahshepses, I, pl. 60).

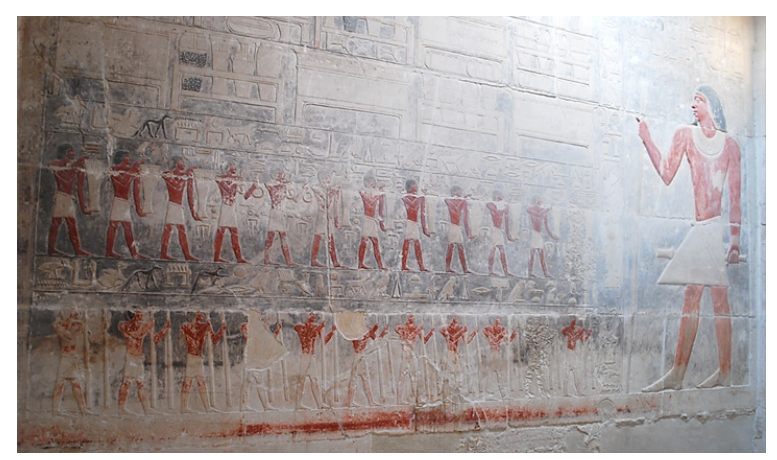

Figure 4A Linen-bearers, North wall- room VIII, Kagemni's tomb (photo by the authors).

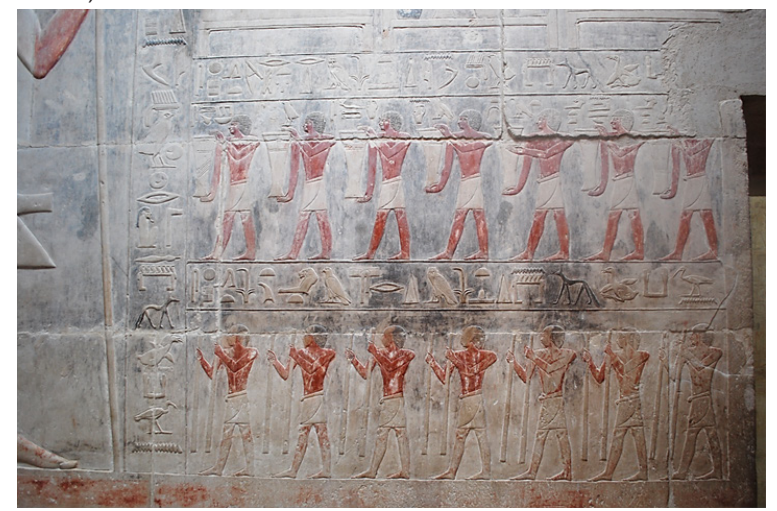

Figure 4B Linen-bearers, South wall- room VIII, Kagemni's tomb (photo by the authors).

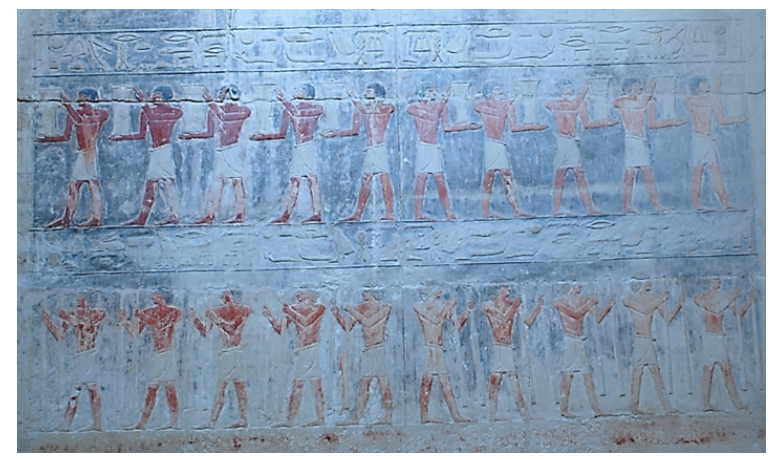

Figure 4C Linen-bearers, East wall- room VIII, Kagemni's tomb (photo by the authors). 


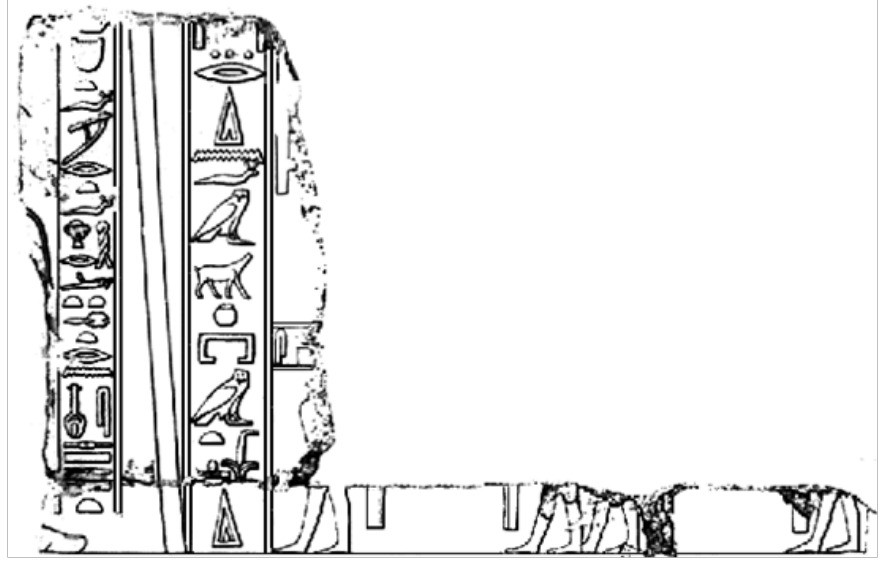

Figure 5A Linen-bearers, Mereruka's tomb, North wall- room A 9 (Duell, Mereruka, I, pl. 73).

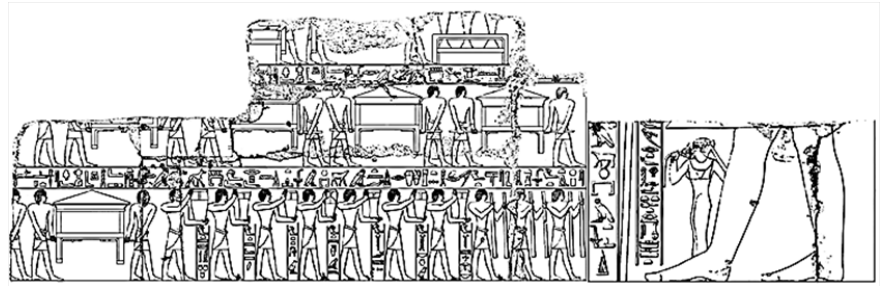

Figure 5B Linen-bearers, Mereruka's tomb, West wall- room A 9 (Duell, Mereruka, I, pls. 7I, 72).

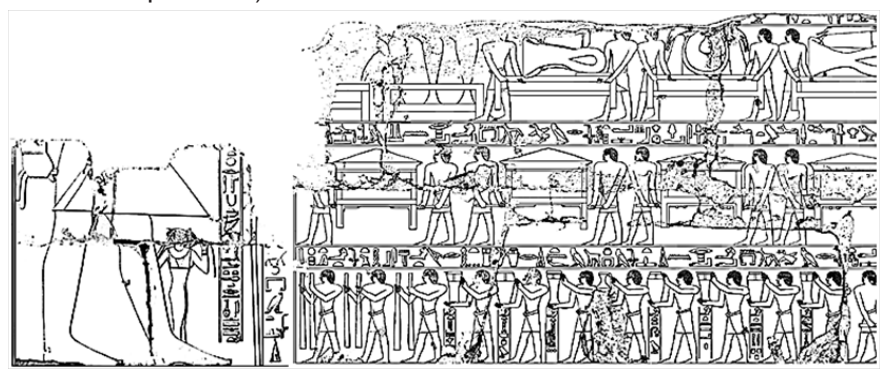

Figure 5C Linen-bearers, Mereruka's tomb, East wall- room A 9 (Duell, Mereruka, I, pls. 7I, 75).

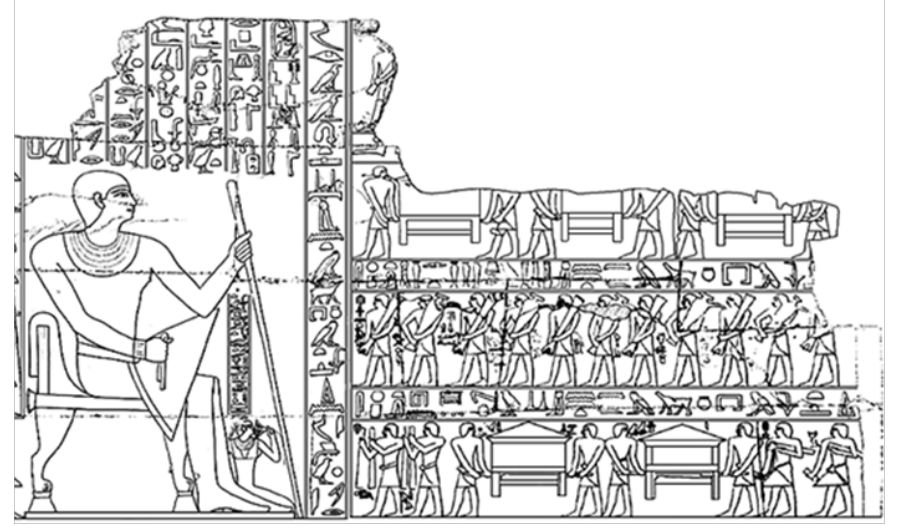

Figure 5D Linen-bearers, Mereruka's tomb, West wall- room A 10 (Duell, Mereruka, I, pls. 96, 99).

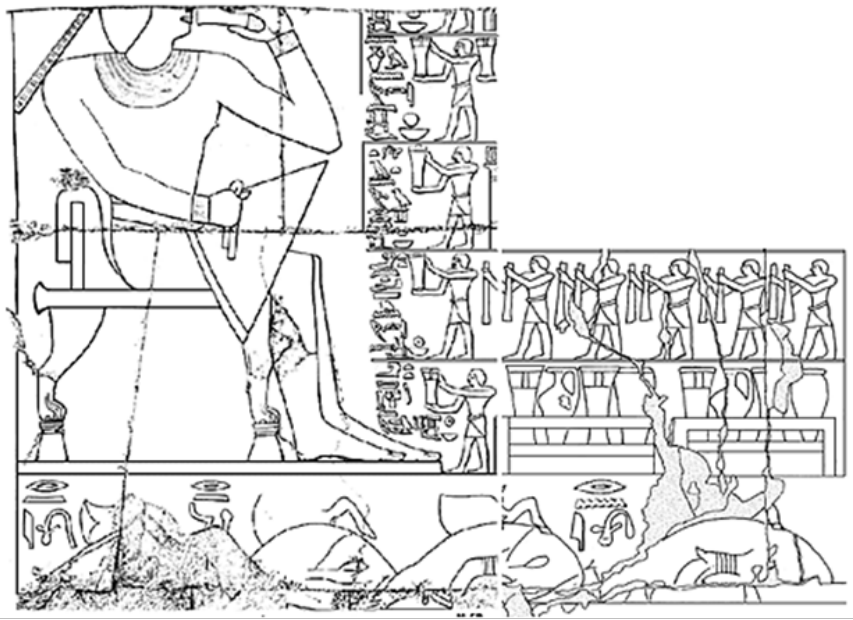

Figure 5E Linen-bearers, Mereruka's tomb, East wall- room A 12 (Duell, Mereruka, II, pl. I I7).

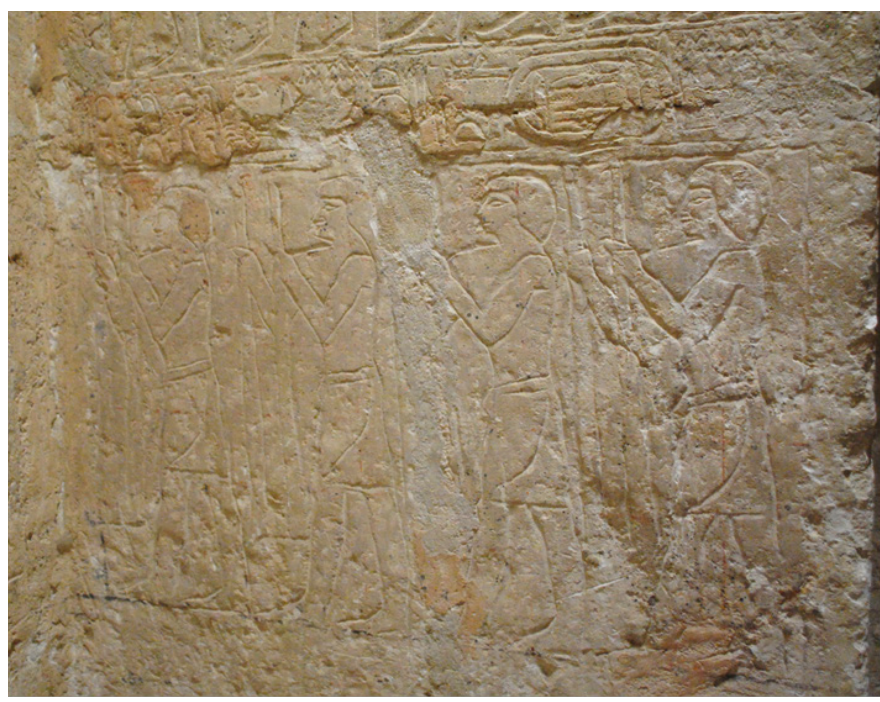

Figure 6A Linen-bearers, Nikauisesi's tomb, East wall- room IV (photo by the authors).

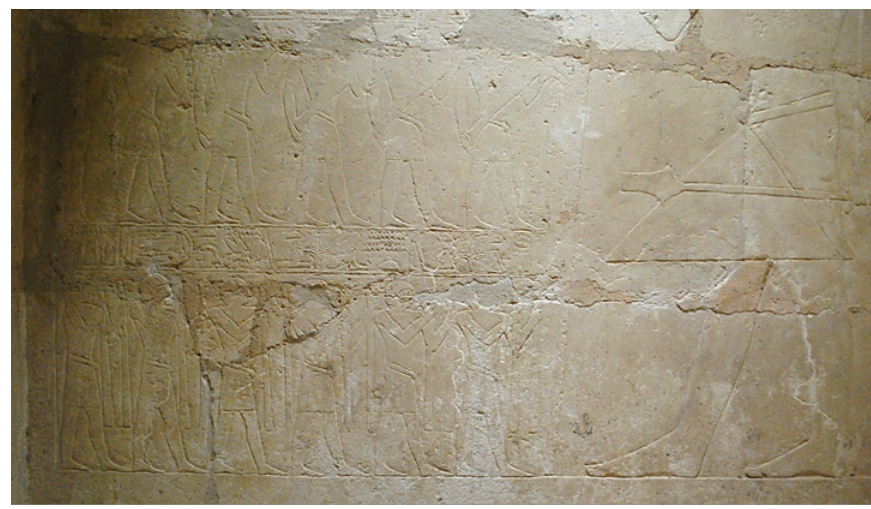

Figure 6B Linen-bearers, Nikauisesi's tomb, West wall- room IV (photo by the authors). 


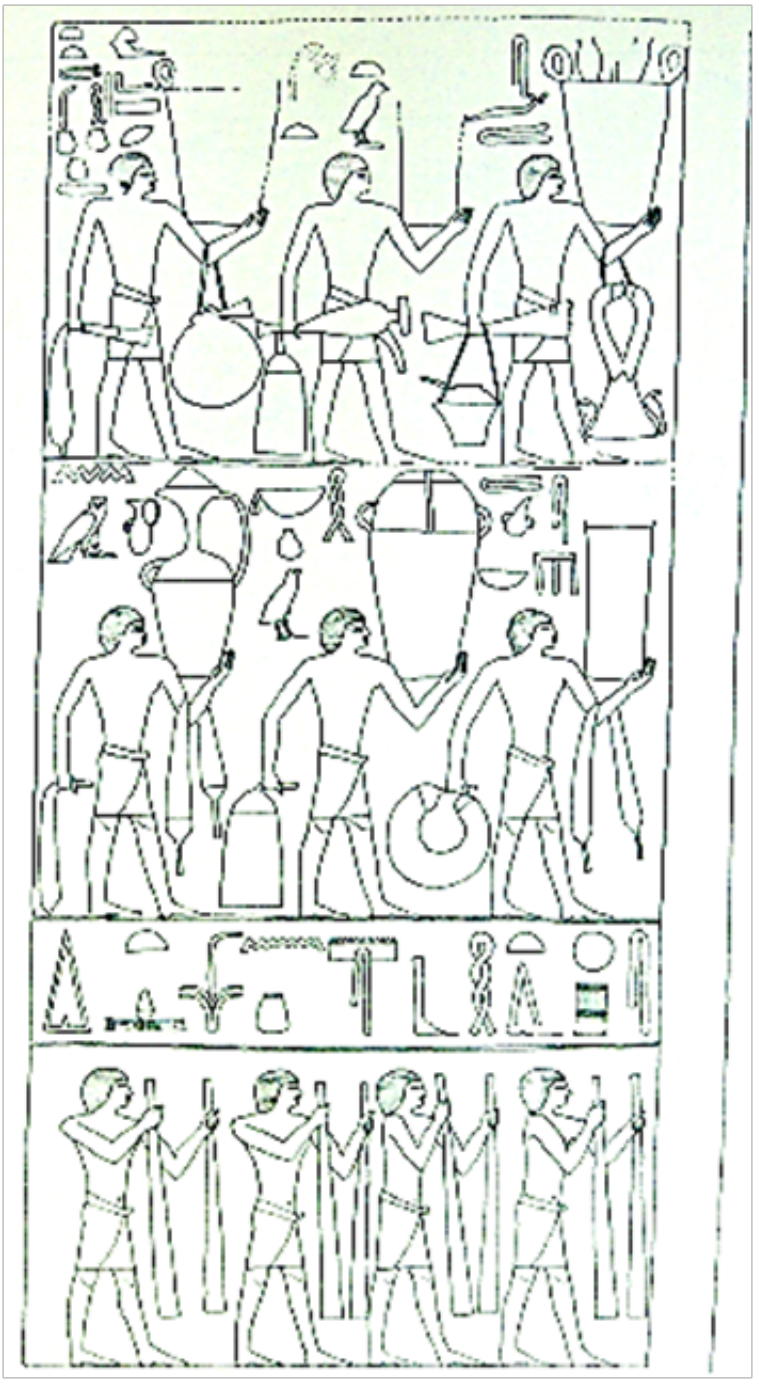

Figure 7A Linen-bearers, Ankhmahor's tomb (Badawy, Nyhetep-Ptah, fig. 43).

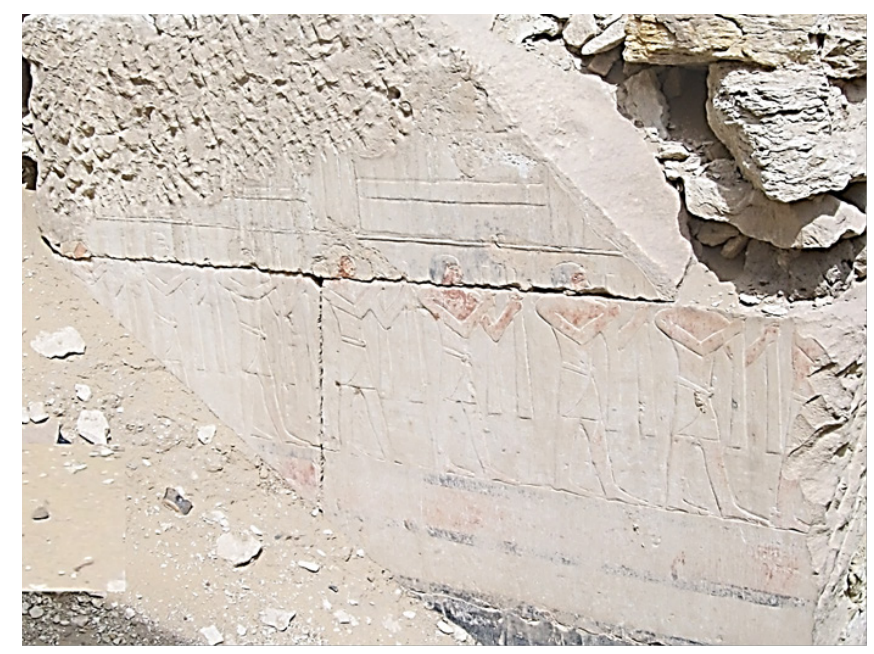

Figure $\mathbf{8 A}$ Linen-bearers, Tetiankh's tomb (photo by the authors).

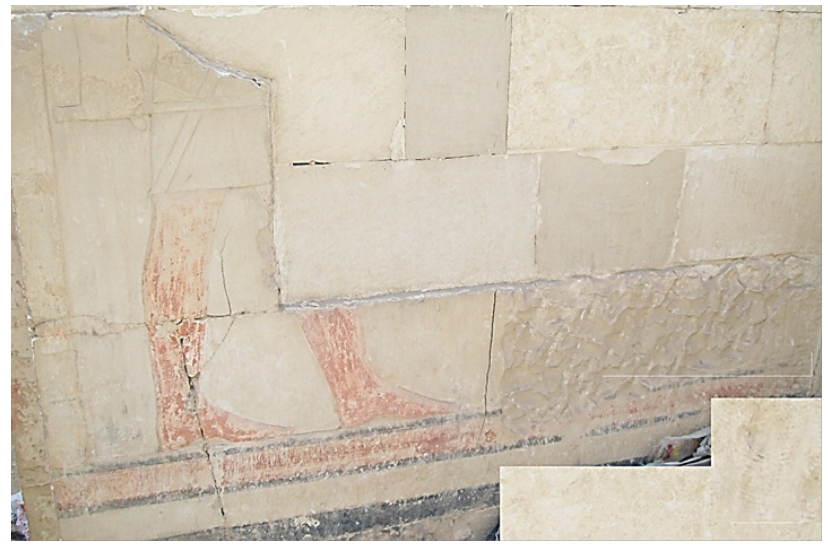

Figure 8B Linen-bearers, Tetiankh's tomb (photo by the authors).

\section{Commentary}

\section{Positions of representations of the Scene}

This scene was usually inscribed in the tombs' super-structures in one room (Nebet, Nebkauhor, Ptahshepses, Kagemni, Nikauisesi, and Tetiankh). It was rarely depicted in several rooms as in the tomb of Mereruka where it is shown in three rooms. That room or these rooms were usually store-rooms and were usually connected to the offering room. This scene can be also seen, rarely, in the chapel as in the tomb of Ptahshepses because the chapel of the tomb has only one room including all the scenes. The reason for the multiplicity of the scene in the tomb of Mereruka is the large area of this tomb and the number of its side rooms and stores, which are dedicated to depict this scene. It is the largest tomb for a noble in the Old Kingdom in terms of the number of rooms and stores.

This scene was depicted in the room on one wall (Nebet, Ptahshepses, and Mereruka-rooms 10 and 12) or two walls, usually the opposite walls (Akhethotep/Hemi, Nikauisesi, and Tetiankh?), or three walls (Kagemni and Mereruka-room 9). These walls were north, south, east and/or west. The scene was rarely inscribed on the entrance thicknesses of the tomb store-rooms (Ankhmahor). The thickness of the doorway is not a suitable place and is not common to depict the scene which needs a large space to show the procession of linen-bearers and the deceased who is watching and receiving the procession and this is appropriate to the walls and not with small positions such as the thicknesses of entrances, jambs of false doors, and faces of pillars. It was represented in either a separate register (Kagemni, Nikauisesi, Ankhmahor and Tetiankh), or neighboring other scenes (Akhethotep, Ptahshepses, and Mereruka). It was frequently the bottom register (Nebkauhor, Kagemni, Mererukarooms 9, 10, Nikauisesi, Ankhmahor, and Tetiankh), and rarely in the middle register (Ptahshepses and Mereruka-east wall of room 12).

The scene was sometimes connected with other scenes; preceded by perfume (Mereruka-east wall of room 12), topped with perfume (Ptahshepses, Kagemni, Ankhmahor, Nikauisesi), perfume and eyepaint (Kagemni), or boxes of cloth (Mereruka, east and west wallsroom A 9) or followed by perfumes and boxes of cloth (Akhethotep and Mereruka- west wall of rooms 9, east and west walls of room 10), or wine (Ptahshepses). Harpur suggested that linen-bearers are associated with perfume or oils bearers because both of cloth and oils 
were essential requirements for the deceased's funeral preparations and his transformation after death. ${ }^{11}$ We think that linen-bearers are mainly preceded, followed, topped by the perfume in order to follow the organization of the offering list where the linen is usually preceded by the perfume and eye-paint. This scene is always depicted in the chapel and is never shown in the burial chamber because the necropolis and period of depicting this scene are Saqqara and the reigns of Unas and Teti. There is no decorated burial chamber with animate figures (because the linen-bearers include animate figures) in Saqqara from the reigns of Unas and Teti. There are only two decorated burial chambers with animate figures in Saqqara. These tombs are not dated to the period of representing this scene. The first tomb is the recent discovered decorated burial chamber of king Isesi's vizier, Reshepses LS 16 (S 902), which is dated to the middle of the reign of Djedkare. ${ }^{12}$ The second tomb is Kairer's tomb which is dated to Pepy I's reign ${ }^{13}$ or Pepy I's-Merenre's reigns. ${ }^{14}$

Table I Positions of representations of the tomb

\begin{tabular}{|c|c|c|c|c|c|}
\hline No. & Tomb & Location & Dating & $\begin{array}{l}\text { Represe n t a t io n s } \\
\text { position }\end{array}$ & References \\
\hline 1 & Nebet Figure I & Saqqara Unas' Cemetery & Fifth Dynasty & $\begin{array}{l}\text { North wall of the magazine } \\
\text { G }\end{array}$ & $\begin{array}{l}\text { PM. III', 624-25; Munro, P., Der Unas- } \\
\text { Friedhof Nord-west, Mainz/ Rhein, } \\
\text { 1993, Taf. } 29,43\end{array}$ \\
\hline 2 & $\begin{array}{l}\text { Akhethotep/ Hemi } \\
\text { Reused later by } \\
\text { Nebkauhor Figure } 2\end{array}$ & Saqqara Unas' Cemetery & Fifth Dynasty & $\begin{array}{l}\text { North and south walls of } \\
\text { the store-room }\end{array}$ & $\begin{array}{l}\text { PM. III', 627-29; Hassan, S., } \\
\text { Excavations at Saqqara, I, Cairo, I975, } \\
\text { 53-55, pls. xlii-xliv }\end{array}$ \\
\hline 3 & Ptahshepses Figure 3 & Saqqara Unas' Cemetery & $\begin{array}{l}\text { Late Fifth Dynasty } \\
\text { and beginning of } \\
\text { Sixth Dynasty }\end{array}$ & East wall of the chapel & $\begin{array}{l}\text { Soleiman, S. and El-Batal, A., The Gisr } \\
\text { el-Mudir Cemetery at Saqqara, vol. } \\
\text { IV, The Tomb of Ptahshepses, part I, } \\
\text { The Tomb Owner, Architecture and } \\
\text { Dating of the Tomb, Cairo, 20I5, pls. } \\
59,60 \text {. }\end{array}$ \\
\hline 4 & Kagemni Figure 4 & Saqqara Teti's Cemetery & Sixth Dynasty & $\begin{array}{l}\text { The south, north and east } \\
\text { walls of the store-room }\end{array}$ & $\begin{array}{l}\text { PM. III', 52I-25; Harpur, Y. and } \\
\text { Scremin, P., The Chapel of Kagemni- } \\
\text { Scene Details, Oxford, 2006, 483, } \\
\text { 485-87, 538, 539, pls. 523, 530, 538, } \\
539 \text {, figs. 35, 36, 38. }\end{array}$ \\
\hline 5 & Mereruka Figure 5 & Saqqara Teti's Cemetery & Sixth Dynasty & $\begin{array}{l}\text { The store-rooms (north } \\
\text { east and west walls of room } \\
9, \text { west wall of room 10, east } \\
\text { wall of room I2) }\end{array}$ & $\begin{array}{l}\text { PM. III', 525-34; Kanawati, N. et al., } \\
\text { Mereruka and his Family, part 3:The } \\
\text { Tomb of Mereruka, Oxford, vol. I, } \\
2010 \text {, pls. } 92,93,100,108 .\end{array}$ \\
\hline 6 & Nikauisesi Figure 6 & Saqqara Teti's Cemetery & Sixth Dynasty & $\begin{array}{l}\text { East and west walls of the } \\
\text { store-room }\end{array}$ & $\begin{array}{l}\text { Kanawati, N. and Abder-Raziq, M., } \\
\text { The Teti Cemetery at Saqqara, vol.VI, } \\
\text { The Tomb of Nikauisesi, Warminster, } \\
2000,5 \text { I-52, pls. } 63,65\end{array}$ \\
\hline 7 & Ankhmahor Figure 7 & Saqqara Teti's Cemetery & Sixth Dynasty & $\begin{array}{l}\text { The south thickness of the } \\
\text { doorway between rooms III, } \\
V \text { (the store-room) }\end{array}$ & $\begin{array}{l}\text { PM. III', 5I2-I5; Badawy,A., The Tomb } \\
\text { of Nyhetep-Ptah at Giza and the } \\
\text { Tomb of cAnkhmcahor at Saqqara, } \\
\text { Berkeley, Los Angeles and London, } \\
\text { I978, fig. 43; Kanawati, N. and Hassan, } \\
\text { A., The Teti Cemetery at Saqqara, vol. } \\
\text { II, The Tomb of Ankhmahor, Sydney, } \\
\text { 1997, 47, pl. 52. }\end{array}$ \\
\hline 8 & Tetiankh Figure 8 & Saqqara Teti's Cemetery & Sixth Dynasty & $\begin{array}{l}\text { The north of the store- } \\
\text { room (perhaps also the } \\
\text { damaged south wall) }\end{array}$ & Unpublished \\
\hline
\end{tabular}

\section{Numbers of processions in the tomb}

It is noticeable that the tomb could include from one to five scenes of linen processions. These tombs included one procession of the linen-bearers (Ptahshepses and Ankhmahor), two (Nebet, Akhethotep, Nikauisesi, and Tetiankh?), four (Kagemni), or five (Mereruka). The tombs dated to Unas' reign usually include one (Ptahshepses) or two processions (Nebet, Akhethotep). The tombs dated to Teti's reign usually include one, two, four, or five processions.

\section{Numbers of linen bearers in the procession}

The number of bearers in the procession varied as follows;

1. Nebet: The scene of Nebet is broken and missing many parts, so we are not sure how many processions were shown. There are remains of only two persons in each procession.

2. Akhethotep: three persons in each procession.

\footnotetext{
${ }^{11}$ Harpur and Paolo, Kagemni, p. 483.
} 
3. Ptahshepses: five persons.

4. Kagemni: five persons (twice), seven and eleven.

5. Mereruka: two, three, five (twice).

6. Ankhmahor: four persons.

7. Nikauisesi: four and six persons.

8. Tetiankh: eight persons.

It is noticeable that each procession consists of two to eleven persons according to the allocated space to this scene in the tomb.

\section{Direction of the procession}

Most of the processions faced towards the deceased on the same wall or on the neighboring wall (Nebkauhor, Ptahshepses, Kagemni, Mereruka, Nikauisesi, and Tetiankh?) in order to be examined by the deceased to be happy and to ensure the requirements of his eternal life. A few were directed to the store-room itself (Ankhmahor) in order to be stored for the benefit of the deceased.

\section{Distribution of this scene in the old kingdom cemeteries}

This scene was depicted only in Saqqara. It was found in two Cemeteries: Unas' Cemetery (Nebet, Akhethotep/Hemi, and Ptahshepses), and Teti's Cemetery (Kagemni, Mereruka, Nikauisesi, Ankhmahor, and Tetiankh). We believe the existence of this scene in that area and those two cemeteries is that the procession only appeared in the era of Unas and Teti and is therefore linked to their cemeteries in Saqqara.

\section{Identity of the tombs owners who depicted linen bearers}

This scene was inscribed in the Fifth Dynasty by the royal family members: Nebet was a queen and wife of Unas; Akhethotep-Hemi was a prince, chief of justice and minister. ${ }^{15}$ Also the high officials depicted it: Ptahshepses was inspector of the royal domain, inspector of the great house, inspector of the robing-room, lector priest, overseer of the two granaries, overseer of the two treasuries, overseer of the two houses of gold, overseer of the two workshops, overseer of the linen house, overseer of the commissions of the great house, $h m-n t r_{\text {_ }}$ priest of (the pyramid) 'perfect-is-Izezi', $h m-n t t_{-}$priest of (the pyramid) 'perfect-are-the-places-of-Wenis', and $h m-n t$ I $_{\text {_ }}$ priest of (the pyramid) 'steadfast-are-the places-of-Teti' ${ }^{16}$ In the sixth Dynasty the members of the royal family (Tetiankh) and four high officials depicted that

${ }^{12} \mathrm{PM}$. III ${ }^{2}, 494-96 ;$ Baer K. Rank and Title in the Old Kingdom, Chicago, 1960, p. 101, 292; Strudwick NC. The Administration of Egypt in the Old Kingdom, London, 1985, p. 94-95; Harpur Y. Decoration in Egyptian Tombs of the Old Kingdom, Oxford, 1987, p. 336; Cherpion N. Mastabas et hypogées d'Ancien Empire - Le probléme de la datation, Brussels, 1989, p. 229; El-Tayeb H. The burial chamber of Rashepses at Saqqara, EA 44 (Spring 2014), p. 8-9.

${ }^{13}$ Harpur, Decoration. p. 197-98, 276.

${ }^{14}$ Dawood K. Animate decoration and burial chambers of private Tombs during the Old Kingdom, New evidence from the Tomb of Kairer at Saqqara, in: Pantalacci L.et Berger-el-Naggar C. editors, Des Néferkarê aux Montouhotep. Travaux archéologiques sur la fin de la VIe dynastie et la première Période Intermédiaire, Lyon, 2005, p. 116.

${ }^{15} \mathrm{PM} . \mathrm{III}^{2}, 624,627$.

${ }^{16}$ Soleiman S. and El-Batal A. The Gisr el-Mudir Cemetery at Saqqara, vol. IV, The Tomb of Ptahshepses, part I, The Tomb Owner, Architecture and Dating of the Tomb, Cairo, 2015, p. 21-37. procession; three of them were also chiefs of justice and ministers (Kagemni, Mereruka, and Ankhmahor); the first two of them married two daughters of king Teti. Nikauisesi was a count, Overseer of the two houses of the gold, Overseer of the two workshops, Overseer of Upper Egypt etc... ${ }^{17}$ The linen bearers' procession started as a royal tradition then the high officials imitated it.

\section{Inscriptions accompanying the linen bearers}

There are inscriptions above the linen procession in the tomb of Ptahshepses consisting of:

1. The short offering formula:

htp di nzwt nzwt-sšr: an offering that the king gives the royal linen.

2. Types, names and numbers of the linen. The inscriptions are not in good condition, so we are not sure if the linen is divided into one or two groups $(s \check{s} r, 3 t)$. It is of w-name. The numbers are from 5000 to 9000 .

There is a horizontal line above the procession in the tombs of Sixth Dynasty describing the action. This line does not exist in the tombs of the Fifth Dynasty. So the scene of the linen procession scene in the tomb of Ptahshepses is dated to the Fifth Dynasty, not to the Sixth Dynasty because this line is not present (the decoration of this tomb started in the reign of Unas and continued during the reign of Teti so some scenes are dated to Unas and others dated to Teti).

The horizontal line consists of;

1. The infinitive shpt which means bringing, to describe what the linen bearers are doing.

2. The linen types:

a. $s \check{r} r \quad n s w t f \quad h 3 t \quad s \check{s} r \quad n s w t$, the royal linen/ the best royal linen (Kagemni, Nikauisesi, and Mereruka).

b. hatiw (Kagemni).

c. $h b s$ clothe (Mereruka and Ankhmahor).

d. $W n h w$ clothes material (Kagemni)

3. The origin of this linen is from the residence as a royal offering. We have this information from the reign of Isesi in the tomb of Kaemthenent who mentioned in his autobiography that the king rewarded him with linen from the residence after his safe and successful journey with the king. ${ }^{18}$

4. The titles and name of the tomb owner, to whom this linen was brought.

\section{Dating}

This scene appeared since late Fifth Dynasty and continued in the early Sixth Dynasty.

A. Late fifth dynasty: it appeared in three tombs dated to Unas' reign; Nebet, ${ }^{19}$ Akhethotep/Hemi, ${ }^{20}$ and Ptahshepses. ${ }^{21}$

\footnotetext{
${ }^{17}$ Kanawati, Nikauisesi, p. 11-12

${ }^{18}$ Strudwick NC. Texts from the Pyramid Age, Leiden/Boston, 2005, p 284-285.

${ }^{19}$ Cherpion, Mastabas, p. 233.

${ }^{20}$ Kanawati N. The Egyptian Administration in the Old Kingdom, Warminster,

1977, p. 152; Strudwick, Administration, p. 56-57; Harpur, Decoration, p. 274.

${ }^{21}$ Soleiman and El-Batal, Ptahshepses, I, p. 77-100.
} 
B. Early sixth dynasty: This scene continued in five tombs dated to the Sixth Dynasty. Kagemni, ${ }^{22}$ Mereruka, ${ }^{23}$ Nikauisesi, ${ }^{24}$ and Tetiankh are dated to Teti's reign and tomb of Ankhmahor is dated to the reign of Teti or Pepy I. ${ }^{25}$ It is clear, regardless of the tomb which the scholars differ on its dating, that this scene is related to the reigns of Unas and Teti.

\footnotetext{
${ }^{22}$ Harpur, Decoration, p. 276 [534]; Baer, Rank, p. 295 [548]; Kanawati, Administration, p. 155 [361]; Strudwick, Texts, 154-55 [151]; Cherpion, Mastabas, p. 230.

${ }^{23}$ Ibid, 230; Baer, Rank, p. 82 [197]; Strudwick, Administration, p. 100-101 [68]; Harpur, Decoration, p. 274 [420]; Kanawati, N. et al., Mereruka and his Family, part 3, The Tomb of Mereruka, vol. I, Oxford, 2010, p. 32-33.

${ }^{24}$ Kanawati and Abder-Raziq, Nikauisesi, p. 17-23.

${ }^{25}$ Baer, Rank, p. 64 [94]; Strudwick, Administration, p. 75 [30]; Harpur, Decoration, p. 273 [374]; Cherpion, Mastabas, p. 153, 232; Kanawati and Hassan, Ankhmahor, p. 18.
}

\section{Acknowledgments}

We would like to thank Annette Gary, who reviewed the English of this article.

\section{Funding}

None.

\section{Conflicts of interest}

Author declares that there is no conflict of interest. 